\title{
わが国の都市の近年の湿度変化
}

\section{Recent Changes in Trends of Humidity of Japanese Cities}

\author{
小元敬男* ・鱧谷 憲* ・ 嚴香姫* （大阪府立大学農学部） \\ Yukio OMOTO, Ken HAMOTANI, Hyang Hee UM College of Agriculture, Uni. Osaka Prefecture
}

\begin{abstract}
Rapid decrease in relative humidity at urban climatological stations in Japan during 1950's and 1960's abruptly ended around 1970. Since then the annual mean of relative humidity has remained at almost the same level excepting interannual variation. The recent trends are even suggestive of its increase for data at stations in big cities such as Tokyo and Osaka. It is important to note that apparent decreasing trends prevail recent years at stations in rural areas instead. The differences between urban climatological stations with near-by rural stations in both relative humidity and vapor pressure are decreasing recent $10 \sim 20$ years. It is shown that during the rapid drying period both the effects of water vapor pressure decrease and temperature rise worked effectively. The recent decrease in urban-rural difference due not only to drying of rural areas noted above but also to increase in the water vapour contents in the urban atmosphere, latter by human activities. At the present urban-rural difference in relative humidity at Tokyo and Osaka are largely attributable to urban warming. It is also demonstrated that urban drying reduces discomfort from hot and humid climate in summer at large cities west of Tokyo.
\end{abstract}

Key words: urban climate, humidity, drying, water vapor, discomfort index.

日本の都市の気象台のデータは1950年代と1960年代に急速な乾燥化を示したが, 1970年頃に変化傾向が急変し, 年間の変動を除い て以後ほほ一定になっている. 東京や大阪のデータは相対湿度の増加傾向すら示唆している. 一方, 非都市域の気象官署では最近明 眹な乾燥化が䘽測されている.このため相対湿度及び水蒸気圧の都市内外声は近年, 隇少傾向になっている.急速な乾燥化の起こっ ていた時期には, 水蒸気量の減少と昇温が同時的に相対湿度を低下させていた。最近の湿度の都市内外差の減少は非都市域の乾燥化 という相対的なものだけではなく,様々な人間活動による都市大気への水蒸気の放出量の増加の効果も寄与している. 今日の東京及 び大阪における都心部と郊外の相対湿度の差はほほ温度差に起因している，わが国の大都市に扔りる乾煤化は夏の蒸し暑さを僅か ではあるが和らげる効果をもたらしている。

キーワード：都市気候, 相対湿度, 乾燥化, 水蒸気, 不快指数.

\section{I 、はじめに}

わが国では大都市は都市気候のためにかなり乾燥 しており，乾燥化は現在も進行中であると一般に考 えられている.そして，これによって環境は更に悪 化すると骿念する向きもある. 確かに, 東京や大阪 にお抽合の相対湿度は戦前に比べるとかなり低 い.しかし，それは1950年代から1960年代にかけて の急速な乾燥化の影響が残っているからであって,
例えば東京や大阪では1970年前後から，年々の変動 はあるが相対湿度の低下傾向はほとんど見られなく なっている(小元，1982；1983；1988). 西日本の大都 市における乾燥化は, 夏の蒸し暑さを和らげる効果 を持っており，環境悪化とは言えないのである。

ここで湿度に関連する用語の定義について触れて おきたい. 俗に湿度と呼ばれているのは相対湿度で, その定義は「実際の水蒸気圧の同温度の飽和水蒸気 圧にたいする百分比」である。湿度は正しくは「大

\footnotetext{
-大阪府立大学農学部 $\overline{7} 593$ 堺市学園町 $1-1$

College of Agriculture, Univ. Osaka Prefecture. 1-1 Gakuencho, Sakai City, 593
} 
気がどれくらい水蒸気をふくむかを量的にしめす概 念(斉藤, 1985)である. 大気中の水蒸気量の表現法 は幾つもあり, 気象学系では単位体積中の水蒸気量 $\left(\mathrm{g} / \mathrm{m}^{3}\right)$ を, 工学系では単位質量のしめり空気に含ま れる水蒸気量 $\left(\mathrm{kg} / \mathrm{kg}^{\prime}\right)$ を絶対湿度と定義している。 なお工学系の絶対湿度は気象学系の比湿に対応する 〔括弧内は単位〕。

都市の湿度に関する文献は相対湿度に注目してい るものが多く, 乾燥化が強調されがちである，一方， 水蒸気圧・絶対湿度など水蒸気量に注目した論文で は，夜間と早朝には市街地の方が郊外よりも湿って いることを指摘する (Chandler, 1967 ；Hage, 1975 ； Hilberg, 1978 ; Ackerman, 1987 ：Lee, 1991). かが国 の大都市については乾燥化に注目している論文や報 告が圧倒的に多いが, 関口 (1963) はヒートアイラン ドの発達した早朝，都心部ては郊外よりも相対湿度 が低かったにもかかわらず水蒸気圧はむしろ高かっ た観測例を示している。な乾燥・半乾燥気候の地 域における潅溉によって緑化された都市では, 日中 夜間を問わずwet islandになっていると考えられる が具体例の報告は手元にない.

\section{П . わが国の大・中都市における相対湿度の}

变化

大都市の都心に位置する東京及び大阪の両管区気 象台ならびに，小都市または非都市域の観測所であ る勝浦及び洲本の両測候所の相対湿度の推移を図 -1 に示す. 年平均值の変動は比較的小さいことも あって，都市気象台に扔けるトレンドの不連続的な 変化が一目で判る. 東京など関東の都市では1940年

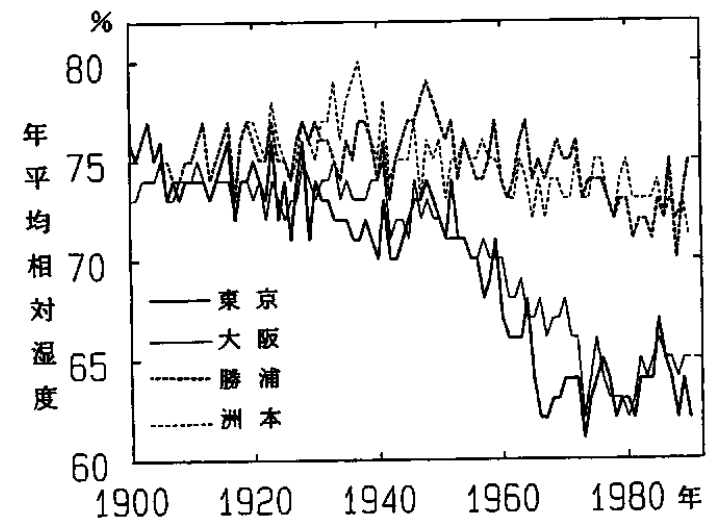

図一1東京・大阪・勝浦及び洲本における年平均 相対湿度の推移
代後半から50年代始めにかけて一時的に相対湿度の 高かった時期があった。これを終戦前後のわが国の 疲弊による産業活動の低下の影響と見る向きもある が (荒川，1969；荒川ら，1970)，小元・鳢谷 (1982) の都市効果の計算結果は, この期間の相対湿度の増 加はむしろ自然変化による分が大きいことを示唆し ている。

1950年代に入ってからのわが国の急速な復興, 特 に工業化と市街地の拡大は国内諸都市に著しい乾燥 化をもたらした。この期間に東京と大阪では年平均 相対湿度が約11\%低下した。乾燥化の開始年はほほ 同じで1948〜1950年であるが，その終了は東京の 1966年に対して大阪は1973年と約 7 年の遅れがある. なお，両都市の相対湿度の回復傾向は1985年あたり で終わり再び乾燥化の兆しがみえるようにも思われ る. 京都の年平均湿度の都市効果は盆地の影響も あって人口の割に大きいが, 変化傾向は東京及び大 阪とは異なり, 短周期の増減を繰り返しながら, 今 世紀初頭から最近まで下がり続けている.

関東の中都市にある気象官署でも変化量は小さい が東京・大阪と似た相対湿度の変化が観測されてい る (図一2)。これらの都市の気象官署は, 1950年代 の始め頃まではどちらかというと市街地の外にあっ た。 今日もやはり都心とは言えないが市街地に位置 する観測所と見られるようになっている。このよう な市街地と観測地点との位置関係の変化も無視でき ない. 気象台・測候所の値がどのていどその都市の 代表値と見なせるかは重要かつ難しい問題である。

東京と大阪の乾燥化が収まっている近年, 勝浦と 洲本で相対湿度の低下が観測されるようになった

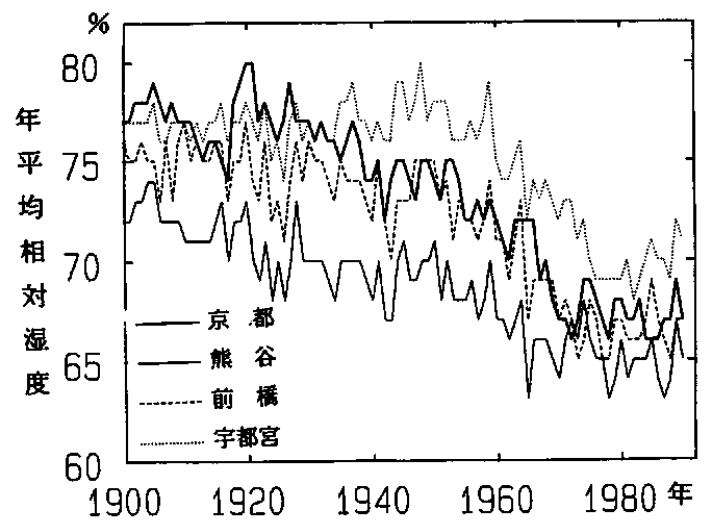

図一2 京都・前橋・熊谷・宇都宮における年平均 相対湿度の推移 
表一 1 関東及び近数における気象官署の年平均相 対湿度の变化傾向の例

(1971-1990の一次回㷌係数；\%/yr）

〔危険率*は0.05；**は0.025〕

\begin{tabular}{|ll|l|ll|l|}
\hline \multicolumn{2}{|c|}{ 関 } & 東 & \multicolumn{3}{c|}{ 近 } \\
\hline 東 & 京 & +0.023 & 大 & 阪 & +0.030 \\
\hline 膡 & 浦 & $-0.100^{*}$ & 洲 & 本 & $-0.097^{* *}$ \\
\hline 館 & 野 & +0.012 & 神 & 戸 & +0.004 \\
\hline 宇 都 宮 & -0.066 & 奈 & 良 & $-0.125^{* *}$ \\
\hline 日 & 光 & -0.123 & 京 & 都 & -0.020 \\
\hline 白 & 河 & -0.059 & 豊 & 岡 & $-0.074^{*}$ \\
\hline 熊 & 谷 & +0.002 & 彦 & 根 & $-0.074^{*}$ \\
\hline 秩 & 父 & $-0.091^{*}$ & 上 & 野 & $-0.155^{* *}$ \\
\hline
\end{tabular}

（図一 1)．表一 1 に大・中都市の気象官署とそれぞ れに比較的近い官署の $1971 \sim 1990$ 年の 20 年間の年平 均相対湿度の一次回㷌式の係数を示す．東京及び大 阪にはかなり大きな十値が得られており，神戸，熊 谷及び館野も十である.しかし期間が短いことも あって変化傾向の有意性を調べてみると, 危険率 $5 \%$ では, +すなわち湿潤化傾向が有意と判定され る地点はない.これに対して小都市あるいは都市気 候の影響のない官署で減少傾向つまり乾燥化が有意 と判定された所が数力所ある(表一1). 都市気候の 影響のあまりない観測所の相対湿度が確実に低下し ていることも興味深いが，その原因の分析などは省 略する。

\section{III. 相対湿度变化における温度効果と水蒸気 効果}

乾燥化の説明に主に用いられる相対湿度は水蒸気 量と気温の関数であり，その変化の解明にはどうし ても水蒸気量及び気温それぞれの乾燥化への寄与の 評価が必要であり, 以下にその評価結果を示す.こ れに使用した方法による他の事例は解説などに示し てきたが(小元, $1983 ； 1988)$, 結果のみを示した場合 が多かったので，以下にその方法を簡単に説明する。

\section{1）都市奻果の評価法}

注目の都市気象台 $\mathrm{A}$ に抢ける気温 $(T)$, 相対湿度 $(H)$, 水蒸気圧 $(V)$ など気候要素の観測値 $M_{o}(A)$ を, 都市気候の影響がなければ観測されたであろう 值 $M_{n}(A)$ [以下でこれを自然值と呼ぶ］と都市効果 $M_{U}(A)$ 和と考える.すなわち，

$$
M_{o}(A)=M_{n}(A)+M_{U}(A)
$$

左辺は観測值で問題ないが，右辺の 2 項については 少なくとも一方を何らかの方法で求めなければなら ない.小元・鳢谷 (1979) は i 年におけるA気象台の 自然値と都市効果を以下のようにして求めることを 提案した。 まず, 自然值について, Aの比較的近く にある都市気候の影響を受けていない観測所Cの デー夕を用いて次式から求める，すなわち，

$$
\begin{aligned}
M_{n}(A)_{i}= & M_{o}(A)_{i}+\Delta M_{30}(A, C) \\
& -\Delta M_{5}(A, C)_{i} .
\end{aligned}
$$

ここで,

$$
\begin{aligned}
& \Delta_{30} M(A, C)={\overline{M_{o}(A)^{30}}}_{i}-{\overline{M_{o}(C)^{30}}}_{i} \\
& \Delta M_{5}(A, C)_{i}=\bar{M}_{o}(A)_{i}-\bar{M}_{o}(C)_{i}
\end{aligned}
$$

但し， $1 \leqq i \leqq 30$

なお $\left(-^{m}\right)$ は $\mathrm{m}$ 年平均を意味する. $\Delta M_{5}(A, C)_{i}$ は $i$ 年を中心とする 5 年間における $A$ と $C$ の差の平 均値である. $\Delta_{30} M(A, C)$ は $A$ とCのデータセット が得られる最初の 30 年間の両地点の差の平均値であ $\eta, A \cdot C$ 間に自然状態で存在するであろう気候差と 仮定される.このことは, $i=1 〜 30$ の期間に招ける $A$ の平均都市効果は 0 と仮定することに相当する. 勿論，実際はそうでなくその分の過少評価になる. この問題については改めて検討する. から $A$ 気象台 における都市効果 $\Delta M_{U}(A)$ は, 式の(1), (2)から次式 で表される。

$$
\Delta M_{U}(A)_{i}=\Delta_{5} M(A, C)_{i}-\Delta M_{30}(A, C)
$$

本式は $i$ 年における都市効果はその年を中心とした 5 年平均値として求められることを意味する. 単年 度の值を求めようとすると, 信頼性に問題のある年 毎の大きな変動があらわれるために好ましくない. 3 年平均で十分かも知れないがこの種の研究では一 般に 5 年移動平均が用いられるのでこのようにした.

さて, 真の都市効果を $\Delta M^{*}{ }_{U}(A)_{i}$ とすると, 上記の 種々の仮定や気候データの性質上,

$$
\Delta M^{\sharp}{ }_{u}(A)_{i}=\Delta M_{U}(A)_{i}+E
$$

となることが考えられる．ここで $\mathrm{E}$ は誤差に相当す るものであるが, それを, $\Delta M_{30}(A, C)$ の導入に係わ る誤差 $E_{1}, 5$ 年移動平均を用いることによる誤差 $E_{2}$, その他の原因による誤差 $E_{3}$ とすると次式のよう に表される、すなわち,

$$
E=E_{1}+E_{2}+E_{3}
$$

ここで $E_{2}$ と $E_{3}$ は評価が極めて困難なのでとりあえ ず無視して,

$$
E=E_{1}=E^{*}
$$

と仮定し，それに伴ってこの補正をおこなった都市 効果を $\Delta M_{U}^{*}(A)_{i}$ と書く.すなわち, 


$$
\Delta M_{U}^{*}(A)_{i}=\Delta M_{U}(A)_{i}+E^{*}
$$

である。

さて, 注目の気象台 $\mathrm{A}$ の観測暦が長くとも比較観 測所Cの観測暦が短ければ, $i=1$ は比較的近年にな り $i \leqq 30$ の期間に Aのデータはすでに相当都市気候 の影響を受けおり, $E^{*}$ の值がかなり大くなる可能性 がある. しかし，これを求める客観的な方法はなく， 準経験的に推定するのが関の山である.そこで，こ れによる誤差をできるだけ小さくする目的で，Aの 近くで近年まであまり都市気候の影響を受けていな いと考えられる気象台 Bの観測值を自然值化し〔式 (2)〜4)においてAをBで置き換える.Cは同じで あっても別の地点であってもよい]，その值を用いて Aの自然値あるいは都市効果を求める方法が考案さ れた（小元・鳢谷, $1979 ； 1980)$. 本報では東京につい

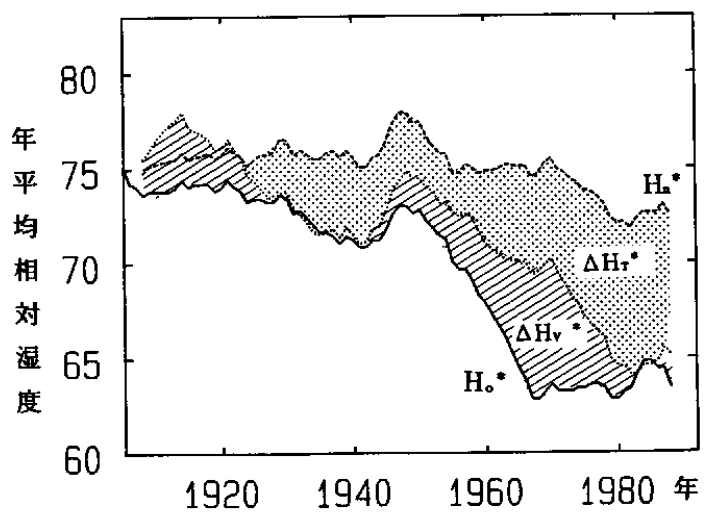

图一3 東京の年平均相対湿度变化にたいする気温 と水蒸気量の都市効果の奇与

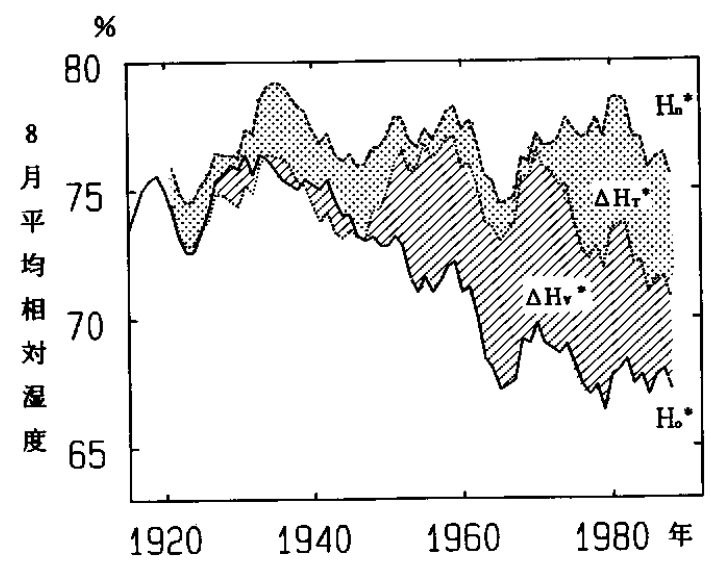

图一 4 大阪の 8 月平均相対湿度変化にたいする気 温と水蒸気量の都市効果の寄与
ては横浜を $\mathrm{B}$ ，勝浦を $\mathrm{C} に ； 大$ 大阪については神戸を $\mathrm{B}$ ，洲本を $\mathrm{C}$ とて計算した。

2 ）相対湿度变化における水蒸気効果と温度効果 相対湿度 $H$ は水蒸気量 $V$ と気温 $T$ の関数であり, 一般に注目されている相対湿度の都市効果 $〔 \Delta H_{U}$, $\Delta H_{v}(A)_{i}$ の省略形，以下同様了は水蒸気量に対する 都市効果 $\Delta H_{V}$ と気温に対する都市効果の寄与 $\Delta H_{T}$ の和と考えることが出来る.すなわち，

$$
\Delta H_{U}=\Delta H_{V}+\Delta H_{T}
$$

ここで $\Delta H_{U}$ 柱相対湿度の累年値から直接計算する ことができる。また， $\Delta H_{v}$ と $\Delta H_{T}$ はそれぞれ気温と 水蒸気圧あるいは相対湿度の累年值から, 飽和水蒸 気圧と気温の関係を表すGoff-Gratchの式 (気象ハン ドブック編集委員会, 1979)を用いて，独立に計算する ことができる。しかし，実際の評価に必要な $\Delta H_{U}^{*}$ の

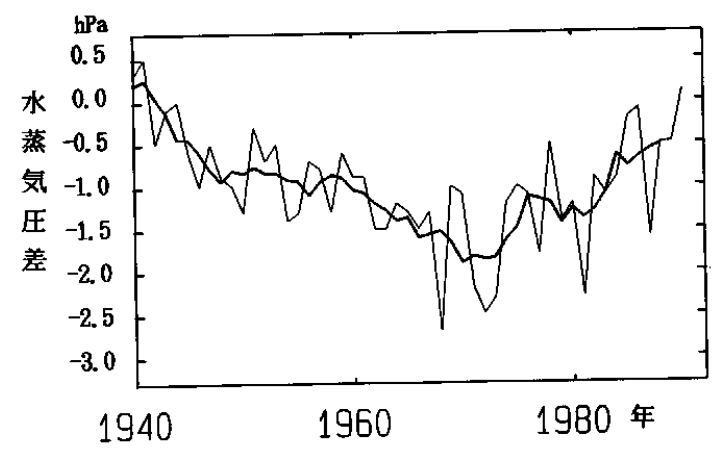

図一 5 大阪及び洲本の 8 月平均水蒸気圧の差の推 移。実線は毎年の值，破線は 5 年移動平均 值

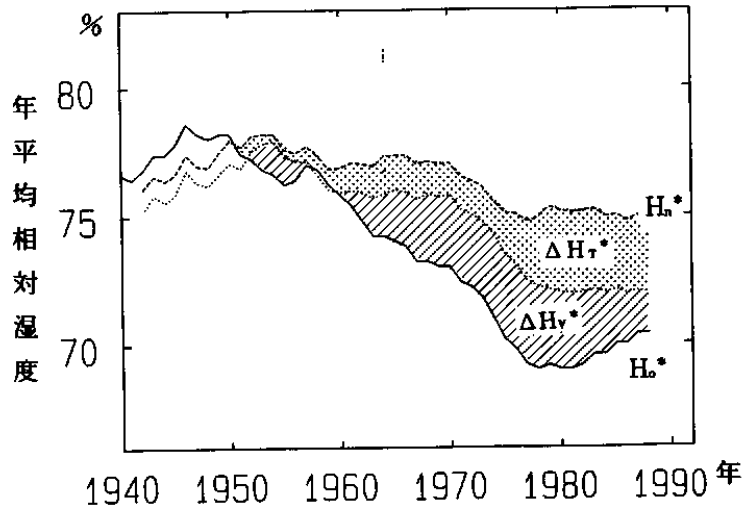

图一6 宇都宮の年平均相対湿度の变化にたいする 気温と水蒸気量の都市効果の寄与 （観測值・自然値ともに5 年移動平均値） 
分析に関しては大きな問題が生じる，それは図一3， 4，6でそのように示されているように，ほんらい，

$$
\Delta H_{U}^{*}=\Delta H^{*}+\Delta H_{T}^{*}
$$

であるべきであるが, 補正項の推定において各項を 独立に求めると，

$$
E_{H}^{*}=E_{V}^{*}+E_{T}^{*}
$$

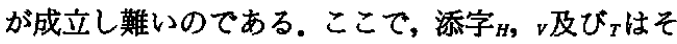
れぞれ相対湿度, 水蒸気圧及び気温に対する補正項 を意味する，したがって，今回はきわめて乱暴であ

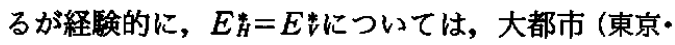
大阪)でー $2 \%$ ，中都市(宇都宮)は一 $1 \%$ とし， $E_{H}^{*}=$ $E^{*}$ すなわち, $E_{T}^{*}=0$ と置いて計算した結果を示す。 したがって図一3，4，6に示された結果について は，傾向的に大きな誴りはないであろうが，定量的 よりむしろ定性的な解釈しかできないと理解するの が無難である.

な㧍, 気温と飽和水蒸気圧の関係はいうまでもな く非線形である.そこで気温と水蒸気圧それぞれの 月平均值及び年平均値から求めた相対湿度の月平均 及び年平均值と，観測値によるそれぞれの平均值を 比較した. その結果, 気温と水蒸気圧の月平均値か ら求めた $\Delta H_{V}$ の月平均值にはあまり大きな誤差を 生じないであろうが，それぞれの年平均値をそのま ま用いて計算した $\Delta H_{V}$ の年平均值は実際とかなり 異なる值になることが判った。本研究における $\Delta H$ の年平均に関わる計算は月平均值から求めたもの である.

\section{3) 解析例}

図一3，4，6にそれぞれ東京(年平均)，大阪 ( 8 月）および宇都宮 (年平均)における相対湿度の都市 効果の分析結果を示す. 上に述べたように都市効果 は 5 年移動平均と等価の形で計算されるのて, 各図 の観測値及び自然值にも 5 年移動平均の平滑化をほ どこしてある.

まず，東京について述べると図一 3 の年平均值は 平滑化によって急激な乾燥化の時期とその前後のゆ るやかな変化が良く示されており, 水蒸気効果と温 度効果の変化も判りやすい. 本図から東京の乾燥化 について次の 3 点を指摘することができる，すなわ ち:(1)急速な乾燥化の期間には昇温と水蒸気量の減 少が同時に起こっていたこと；(2)相対湿度低下が収 まっている期間には水蒸気効果が隇少したこと；(3) 現在も都市内外の相対湿度差は大きいがこれは主に 温度効果によるものであることである.

大阪の相対湿度の都市効果の年変化は東京とかな
り似てはいるが，水蒸気効果が残っているように思 われる.ただし，これには若干の補足説明が必要と 思われる. 図一 4 に大阪 ( 8 月)における相対湿度の 都市効果の分析結果を示す. 実質的に 5 年移動平均 をほどこしてあるにも関わらず変動が大きく全体像 がつかみ難いが, 夏 1 力月の值とは言ってもまだか なり水蒸気効果が残っているように見える. 图一 は大阪と洲本の 8 月平均水蒸気圧の差の推移を示す. 1970年代初めに減少傾向は増加傾向に転じており, 昇温が依然つづいている中で相対湿度の都市効果が ほほ一定に保たれている理由は水蒸気量の増加にほ かならないことは明白である，単年度ではあるが， 1990年 8 月の平均水蒸気圧は大阪の方が洲本よりも $0.1 \mathrm{hPa}$ 高かった。この時の両地点の相対湿度の差 $9 \%$ は全く温度差の効果であることが明かである。 図一 4 において近年の部分に $1 \sim 2 \%$ の水蒸気気効 果が残っていることがこれと矛盾するようであるが， 次の二点のためと理解することができよう。 まず， 大阪と洲本の温度差が全て都市効果でない点である. $1921-1950$ 年の 8 月平均気温で大阪の方が $1.2^{\circ} \mathrm{C}$ 高 い.この期間の大阪の $\Delta T_{U}$ すなわち気温に対する都 市効果は小さく, 自然状態でも大阪の 8 月平均気温 は $1{ }^{\circ} \mathrm{C}$ 近く洲本より高い可能性がある. 次に, $\Delta H_{V}$ は 5 年移動平均的な值であり, 1990年 8 月の平均水 蒸気圧は大阪と洲本の值で一致しているが, その前 後では大阪は洲本より若干低く(図一5) それが計算 上残っているのである.

中都市の乾燥化の例として宇都宮の年平均相対湿 度の変化の解析結果を図一 6 に示す. 都市効果の計 算における比較地点として距離的には日光が近いが, 1982 84年の期間に顕著な相対湿度の低下が観測さ れているので不都合を生じる.そこでNNE約 $80 \mathrm{~km} の$ 白河を対照地点に用いた。 自然值に対する補正量 $E^{*}$ は先に述べたようにー1\%である.1940年代の部分 では温度効果・水蒸気効果共に今日の逆になってい るが,これは先に述べた仮定のためであろう. 宇都 宮の乾燥化が終わったのは1970年代の後半に入って からであるが，その後の年平均相対湿度のゆるやか な増加傾向は東京・大阪の場合と同様に水蒸気奻果 の減少によるものと考えられる。

\section{IV . 湿度のトレンドの变化の原因}

都市の乾燥化の主因としてまず指摘されるのが地 表面の改変である.すなわち，市街地化は樹木を伐 採して地表を不透水性物質で覆うことであり,これ 
によって地表面から大気への水蒸気の供給量が著し く減少すると考えられるからである.確かにこのプ ロセスは乾燥化をもたらす．日本の大都市の市街化 域は拡大の一途を辿っおり，これは一方的な湿度低 下をもたらす．更に，最近やや鈍ってきたとはいえ ほとんどの都市で続いている気温上昇の傾向も, 相 対湿度の低下傾向をもたらす．ところがこれまで示 してきたように，市街地の拡大と昇温の双方が進行 中であるにもかかわらず，都市の急速な相対湿度の 低下傾向は1970年前後に突然終り, 以後ほほ一定か 見方によっては上舁傾向に転じている.

市街地の拡大に伴い, 蒸発散量の減少による乾燥 化の速度は都心部て鈍り始めて当然であるが，それ によって変化傾向が逆転することは起こり得ない筈 である。それが起こったことは，都市の相対湿度を 制御する有力な因子が上記の 2 因子の他にもあり， それは湿度の増加傾向をもたらすものであることを 示唆している．都市における相対湿度の低下率の減 少が都市気候の影響をあまり受けていない観測所て の低下率の増加と同じ期間に発生していることは， この因子が人間活動に関連していることはほほ間違 いない.

都市大気の相対湿度の変化の理解には, 注目の空 間の大気の水収支の計算が理想的であることはいう までもない。しかし，観測精度と観測値の地域代表 性, 観測点の密度, 更には涌源の量的評価などを考 慮すると，現状では信頼できる計算結果を得ること は難しい.ここでは，単に考え方を示し，近年にお ける相対湿度の都市内外差の減少の主因を列挙する に止める。

次の点をまず認識する必要がある。(a)議論は全て 地上気象観測データ，すなわち地上約 $1.5 \mathrm{~m}$ の観測值 に基づいていること：(b)東京，大阪など都市名で表 現されている変化ではあるが, 観測地点 1 力所の値 であり地域代表性に問題があること：(c)調查期間に 観測方法や測器の変更がありその影響が累年データ に含まれているが，これらについての補正は行われ ていないこと：(d)湿度のデータは気温に比べて精度 に難があることである.

ここで，(a)，(b)及び(c)はほほ全ての気象要素につ いて言えることなので，(d)について若干説明してお きたい. 館野高層気象台とその南西 $4 \mathrm{~km}$ に位置する 農業環境技術研究所の気温及び相対湿度について 1982 1990年の期間における月平均值の推移に関す る研究は, 月平均気温の期間平均からの偏差値は気
温の場合には両地点まったく一致するが，相対湿度 には一時期 (1983-1987) 前者のデー夕には全く見ら れない特異な変化が後者に記録されていることが見 いだされた（小元·河村，1993）。変化の様相からこれ が観測方法や測器の変更によるものでないことも明 らかであった．この変化の原因は後者の観測施設付 近の開発の影響と推定されるが，具体的には判って いない，都市の気候に関する記述で，例えば一般に 「東京では」の表現で与えられる值は東京管区気象 台の観測值であり，本報でも都市名で説明している 值は全てその名を冠した気象官署のものである.そ れがどの程度その都市の値と考えてよいかは, 上記 のような局所的効果を無視しても，観測所と市街地 との相対的位置関係を考慮する必要がある.

以上の問題はあるが, 近年わが国の都市で相対湿 度の都市内外差の減少の主因は, (1)都市における人 間活動の放出する水蒸気が著しく增えたこと及び, (2)都市で相対湿度の低下が止まっている時期に郊外 の田園地域における湿度は䋸やかながらも下がりつ づけているという相対的な変化の二つであると考元 られる。ただ，(2)も前者があるから起こっていると も言えるので，実質的には(1)のみを考慮すればよい，

都市内における水蒸気の主な放出源は次の 3 種類 に分類することができそうである.(1)化石燃料の燃 焼 $\left(\mathrm{CO}_{2}\right.$ と共に $\mathrm{H}_{2} \mathrm{O}$ も放出される);(2)者炊・湯进かし など水及びそれを含むものの加熱；(3)冷暖房機その 他水冷式加熱機器の冷却が考えられる.これらそれ ぞれの廃出量が評価されてもそれがどれ位都市湿度 を高めるかの評価が残っているため重要度の順位も 定め難いが, 最近特に増加の傾向にあるのは(3)であ ろう. 湿度の変化傾向の急変の起こった1970年代頃 には(1)の寄与が急速に増えていたと推測される.

最近, 東京と大阪では再び相対湿度の都市内外差 の増加の気配が見られる.特に東京では1985年以降 顕著な年平均相対湿度の低下が観測されている. 気 候デー夕にみられる変動の解明のために, 前記(a) 〜(b)の困難はあるが, やはり都市大気の水収支の定 量的評価が望まれる。

\section{V. 湿度变化の都市環境への影签}

本論から若干外れるが, 誤解されてもいるような ので,ここで相対湿度の変化の都市の環境への影響 について述べてみたい. 都市の乾燥化にしばしば砂 漠化という表現が用いられるが，これは乾燥化は環 境悪化であるという印象を与えている. 砂漠化の議 
表一2 大阪と洲本の 8 月における15時の 平均不快指数

\begin{tabular}{|c|c|c|c|c|c|c|}
\hline & \multicolumn{2}{|r|}{ 大 } & \multicolumn{2}{|l|}{ 阪 } & \multirow{2}{*}{$\frac{\text { 洲 }}{\text { 実 }}$} & \multirow{2}{*}{$\begin{array}{l}\text { 本 } \\
\text { 㗫 }\end{array}$} \\
\hline & 実 & 祭 & 加 & 湿 & & \\
\hline & $\mathrm{H}$ & D I & H & D I & $\mathrm{H}$ & D I \\
\hline 1970 & 59.5 & 81.0 & 70.1 & 82.8 & 70.1 & 80.0 \\
\hline 1980 & 65.3 & 78.8 & 81.2 & 81.8 & 81.2 & 77.2 \\
\hline 1990 & 51.7 & 82.7 & 61.2 & 84.9 & 61.2 & 80.6 \\
\hline
\end{tabular}

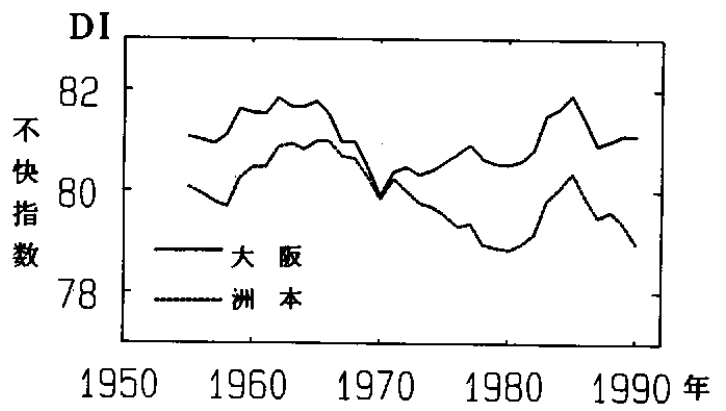

\section{图一7大阪及ひ洲本における毎日15時の不快指数} の 8 月平均値の推移

論に相対湿度を用いること自体が間違いであること は，南米やメキシコ太平洋岸の砂漠地域に年平均相 対湿度が東京や大阪より高い70\%の気象観測所があ ることから明白である.そこが砂漠なのは, 頻繁に 蓩や層雲が発生するが，雨が降らないためである。 このような極端な例は別として，以下に，乾燥化が はたして環境悪化かという問題についてThom （1959）の不快指数（DI）を用いて検討する.

体感気候で不快さを表す指数はKawamuraら (1992)がリトスアップしただけでも10指に余り, 気 温と湿度の二要素から決定される指数も $D I$ の他に 数種類ある. $D I$ が同じ条件でも, 真夏の昼頃は, 直 射日光を浴びているかいないか，あるいは風が吹い ているかいないかで体に感じる暑さが非常に違うこ とは誰もが経験することである。ここでは各種不快 指数の優劣の議論は省略して, 大気湿度の体感気候 に与える影響だけを考えてみたい。この目的にはDI で十分である. 常識的に夏は乾燥しているほど良く, 冬㹥湿っているほど良い.ただDIは冬の寒さを対象 としていないので，ここでは大阪の夏季を例に湿度 変化が実際にどのような影響を不快指数に与えたか について述べる.

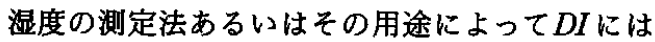
幾つかの計算方法がある。式(4a)，(4b)，(4c)に
Kawamuraら（1992）の挙げた式を示す.

$$
\begin{array}{lr}
D I=0.81 T+0.01 H(0.99 T-14.3)+46.3 \\
D I=0.72\left(T+T_{w}\right)+40.6 & (4 a) \\
D I=T+\frac{1}{3} T_{d}+41.7 & (4 b) \\
&
\end{array}
$$

ここで $T, T_{w}, T_{d}$ はそれぞれ気温(乾球温度), 湿球 温度, 露点温度で $H$ は相対湿度で, 単位は温度 $か^{\circ \circ} \mathrm{C}$, 相対湿度は\%で与えられる。気温と湿度条件 が同じであっても 3 式は違う值を与える，蛇足かも 知れないが, 気温が $0{ }^{\circ} \mathrm{C}$, 相対湿度が $100 \%$ の場合に 3 式のそれぞれが与える值を比較すれば，これが日 本の冬季に使えないことはすぐに判る.

説明し易さの点では，一般になじまれている相対 湿度 $(H)$ を用いる式(4a)が便利である. 表一 2 に大 阪と洲本における1970，1980，1990年の 3 年につい て 8 月の毎日15時の $H$ と $D I$ の平均値の推移を示す. ここで大阪の加湿の欄には気温はそのままで相対湿

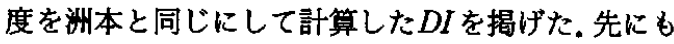
述べたように，表現が国や人によって違うが，一般 には, DIの值が75〜80ならば一部の人が不快, 80〜85の範囲ではかなりの人が不快，85以上となる と全員不快あるいは耐えがたい不快とされている。 その基準からすると実際の相対湿度変化に見る不快 さ(蒸し暑さ)の増減はさほど大きくないが, 乾燥化 が環境悪化でないことは間違いない。

图一7に8月の毎日15時の大阪と洲本における不 快指数の平均值の推移を示す. 5 年移動平均でいう と, 大阪の乾燥化の最も進んだ期間には両者の差が ほとんど無くなっている．年別に言うならば 8 月 15 時の値で，1968，1970，1972，1973年には両者の関 係は逆転している. DIに気温の効果が大きく锄いて いることを認識するのも重要である. 例えば，都市 気候の緩和を目的とした計画において街路樹による 制御は，湿度の増加をもたらすがそれによって更に 蒸し暑くなるとは限らない。蒸散による冷却効果に 加えて日陰を作るからである．湿度は若干増加する であろうが街路樹がビル街の気象環境の改善に奇与 することは間違いないであろう。

\section{VI.むすび}

都市大気に含まれる水蒸気量の変化について気候 学的観点からの分析を試みた。ごく最近の僅かな期 間を除くと，日本の大都市と中都市では乾燥化は約 20 年来止まっている，ところが同じ期間に，都市気 
候の影響の少ない観測所では明らかに相対湿度が低 下している。市街地の拡大と昇温効果を考慮すると 郊外との相対湿度の差が拡がって当然の時期に，そ れが逆に減少していることは，都市内で人間活動の 廃出する水蒸気量の増加を示唆している. それらの 定量的評価なしには断定できないが，化石燃料消費 量の増大, 空調機器を含め各種熱機関の冷却水の蒸 発量の増大，増える人口と日常生活での県炊などに よる水蒸気を発生する行為の増加などがこれを引き 起こしている可能性がある。

人間活動の激化による都市内での水蒸気の放出量 の増加が，樹木を取り払いそこを不透水性の物質で 覆う市街化区域の拡大による地表からの水蒸気の供 給量の減少を上回ってきたと考えても無理はないの ではなかろうか. 本論文では，また乾燥化が環境悪 化ではなく，僅かながらも夏の蒸し暑さを軽減する ことを不快指数の推移から示した。しかしながら体 感気候に対する湿度の奇与はあまり大きくなく，そ れが湿度の増加になっても，日陰を提供し，潜熱の 吸収による冷却効果を持つ街路樹を増やすとか樹木 の豊かな公園緑地を拡大することは気候環境の改良 になると判断してよいであろう。いずれにしても上 記について観測と数値実験による都市大気の水収支 についての定量的評価・予測が必要である。

\section{引用文献}

1) Ackerman, B. (1987):Climatology of Chicago area urban-rural differences in humidity, $\mathrm{J}$. Clim. Appl. Meteorol., 26, pp. 427-430.

2）荒川秀俊 (1969) : 東京の都市化と湿度・温度の 変わり,天気16, pp. 23-24.

3）荒川秀俊 - 片桐勝男 - 常岡好枝 - 貝山久子 - 吉 見則子(1970)：日本の大都市における気温と湿 度の経年変化，天気，17, pp. 239-241。

4 ) Chandler, T.J. (1967): Absolute and relative humidities in towns, Bull. Amer. Meteorol. Soc., 48, 394-399.

5 ) Hage, K.D. (1975): Urban-rural humidity differences, J. Appl. Meteorol., 14, 1277-1283.
6) Hilberg, S.D. (1978): Diurnal temperature and moisture cycles, Ill. State Water Survey Bull., 63, 25-42.

7) Kawamura, T., Ono H.P. and Iwakuma, T. (1992): Geographical distribution of discomfort index over the world, Sci. Rept. Inst. Geosci., Univ. Tsukuba. Sec. A. 13, 113-136.

8) 気象ハンドブック編集委員会 (1979)：気象ハン ドブック，朝倉書店，p. 664 .

9) Lee, D.O. (1991): Urban-rural humidity differences in London, Int. J. Clim., 11, 577-582.

10）小元敬男・觶谷 憲 (1979)：気象官署のデータ からの都市気候効果の消去の試み, 農業気象, 35, pp. 93-96.

11）小元敬男・鱧谷 憲 (1980)：気象官署のデー夕 からの都市気候効果の消去の試み(2), 農業気象, 36, pp. 203-206.

12）小元敬男・鱧谷 憲 (1982)：日本の都市気象台 における近年の湿度の低下について，天気，29， pp. 73-80.

13）小元敬男 (1983)：東京と京都にみる都市気候の 変動, 地理, 28 (12), pp. 26-33.

14）小元敬男 (1988): 都市と気候, 気象研究ノ一 卜, No.162, 211-231.

15）小元敬男・河村 武（1993）:都市域の拡大が大 気湿度に及涩す影響，文部省「人間一環境系」 重点領域研究, 研究報告集, G082-N38B-01, 都 市人工空間における健康影響サーベイランスシ ステム研究報告, 研究代表者 四ツ柳隆夫, pp. 106-119.

16) 斉藤直輔 (1985): 湿度, 気候学・気象学辞典, (吉野正敏ら編)，二宮書店，pp. 220-221

17）関口 武(1963）：平野にある都市内外の気候分 布一一岐鼻県大垣市の場合について，東京教育 大学地理学研究報告, 7, 193-240.

18) Thom, E.C. (1959): The discomfort index, Weatherwise, 12, 57-60.

(1993年 9 月30日受付，1993年11月 8 日受理） 